\title{
LIST KONSTANTYNA DO ALEKSANDRA I ARIUSZA A ZWOLANIE SOBORU NICEJSKIEGO
}

Jedynym datowanym dokumentem z początków tak zwanej „kontrowersji ariańskiej" jest list cesarza Konstantyna do biskupa Aleksandrii Aleksandra i do Ariusza. Tytułem wprowadzenia przyjrzyjmy się jednak krótko całemu blokowi źródeł związanych z tą kontrowersją i Soborem Nicejskim z 325 roku.

Wydawać by się mogło, że z tak ważnego wydarzenia, jakim był pierwszy Sobór Powszechny, powinno być wiele sprawozdań, zwłaszcza że zachowało się sporo dokumentów dotyczących IV wieku. Tak jednak nie jest i trudno to wytłumaczyć inaczej niż przyjmując, że dla jego uczestników wcale nie było to takie ważne. Tak się bowiem składa - i sądzę, że nie przypadkiem - że prawie wszystkie wiadomości, jakie posiadamy o Nicei, pochodzą tylko od dwóch jego uczestników: jest to Euzebiusz z Cezarei, wielbiciel cesarza, wychwalający wszystko, co on zrobił, oraz Atanazy, który na soborze był, ale nie jako pełnoprawny jego uczestnik, lecz jako diakon i sekretarz biskupa Aleksandra. Zachował się także syryjski odpis listu, w którym cesarz zwołuje sobór do Nicei ${ }^{1}$. Na temat kontrowersji ariańskiej mamy listy Aleksandra, Ariusza i Euzebiusza z Nikomedii ${ }^{2}$. Teksty te bywają datowane przez komentatorów w zależności od tego, jak sobie wyobrażają znaczenie wystąpienia Ariusza dla soboru. Jako że powszechnie przyjmuje się, że było ono przyczyną jego zwołania, zakłada się, że musiał upłynąć długi okres czasu, w którym kontrowersja ta mogłaby się rozprzestrzenić na cały Kościół. Tak więc niektórzy datują początek kontrowersji już na rok 318 , inni zaś mówią o roku $323^{3}$. Ważny też jest zachowany po syryjsku dokument synodu w Antiochii z wiosny 325 roku $^{4}$, do którego jeszcze wrócimy.

${ }^{1}$ Por. H.G. Opitz, Athanasius Werke, III/1: Urkunden zur Geschichte des arianischen Streits 318 328, nr 20, Berlin 1934, s. 41-42; zob. tamże dokonany przez E. Schwartza grecki przekład tego listu.

${ }^{2}$ Por. tamże, nr 1-2, 4a-4b, 6, 8, 14-16, s. 1-31.

3 Por. M. Simonetti, La crisi ariana, Roma 1975, 26; C.W. Griggs, Early Egyptian Christianity from its Origins to 451 C.E., w: Coptic Studies, ed. M. Krause, II, Leiden 1990, 160; R. Williams, Arius, Heresy and Tradition, London 1987, 58.

${ }^{4}$ Por. Opitz III/1, nr 18, s. 36-41. 
List Konstantyna do Aleksandra z Aleksandrii i Ariusza zamieścił Euzebiusz z Cezarei w biografii Konstantyna, jak najbardziej panegirycznej ${ }^{5}$. Za nim przepisał fragment tekstu Sokrates Scholastyk ${ }^{6} \mathrm{i}$ inni. Jest to ważne dla zrozumienia jego treści i znaczenia, gdyż Euzebiusz - jak się okazało w późniejszych latach - był bliższy poglądom Ariusza, niż Aleksandra. Sokrates, zdając relację $\mathrm{z}$ interwencji Konstantyna, pisze z perspektywy $\mathrm{V}$ wieku i prawie we wszystkim daje wiarę interpretacji Atanazego. Wbrew pozorom jednak wcale nie jest do końca jasne, o co w nim naprawdę chodzi.

Okoliczności napisania tego listu możemy się tylko domyślać. Wiadomo, że Konstantyn był zajęty wojną domową i wrócił do swego pałacu w Nikomedii najwcześniej we wrześniu 324 roku, po wygranej wojnie z Licyniuszem; ostatnia batalia miała miejsce pod Chrysopolis nad Bosforem 18 września tegoż roku. Na dworze oczekiwał go - zapewne - biskup Hozjusz z Kordoby, jego przyjaciel i doradca od spraw kościelnych, oraz biskup tego miasta - Euzebiusz z Nikomedii. Cesarz, jako Pontifex Maximus odpowiedzialny za wszystkie religie cesarstwa, interesował się żywo problemami Kościoła; dał temu niejednokrotnie wyraz, choćby zwołując synody w sprawach kościelnych ${ }^{7}$. Wśród spraw przedstawionych mu przez Hozjusza, a może i przez innych jeszcze doradców, była również kontrowersja zaistniała pomiędzy biskupem Aleksandrem, a prezbiterem Kościoła aleksandryjskiego, Ariuszem.

Cesarz miał jednak również inne zmartwienia dotyczące Kościoła. W roku 313, kiedy uznał chrześcijaństwo za pełnoprawną religię w Cesarstwie, nie miał on żadnych wątpliwości co do tego, że jego kompetencje najwyższego pontyfika rozciągają się również na Kościół. Nikt również spośród biskupów takich wątpliwości nie miał: jego nadzór nad Kościołem był niekwestionowany. Przy okazji zwróćmy uwagę, że greckie słowo عлiøxoлos oznacza nadzorującego, mającego pieczę nad czymś. Dlatego też Euzebiusz z Cezarei napisze, że Konstantyn jest „,biskupem powszechnym”. . Jego uprawnienia nie płynęły z powołania przez innych biskupów, już to przez głosowanie, już to przez nałożenia rąk, jak w przypadku „Zwykłych” biskupów, ale z natury rzeczy, dlatego że był imperatorem, a jako taki - najwyższym pontyfikiem. Posiadał więc władzę nad kultem, władzę nauczania i rządzenia ${ }^{9}$. Dlatego też rozporządzenia poszczególnych biskupów lub synodów mogą mieć znaczenie dla Kościoła w całym cesar-

${ }^{5}$ Por. Epistola Constantini ad Alexandrum Alexandrinum et Arium, w: Eusebius, Vita Constantini II 64-72; ed. J.A. Heikel, GCS 7, 67-71 lub ed. F. Winkelmann, GCS 7a, 74-79.

${ }^{6}$ Por. Socrates, HE I 7, PG 67, 56-60, tłum. S. Kazikowski: Sokrates Scholastyk, Historia Kościoła, Warszawa 1972, 24-27.

7 Na przykład w Rzymie (313), SCL 1, 62; w Arles (314), SCL 1, 68-74; zob. S. Bralewski, Imperatorzy późnego Cesarstwa Rzymskiego wobec zgromadzeń biskupów, Byzantina Lodziensia 1. Łódź 1997, 23-27.

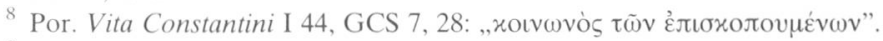

9 Por. R. Farina, L'Impero e l'Imperatore cristiano in Eusebio di Cesarea. La prima teologia politica del cristianesimo, Zürich 1966, 240-242. 
stwie tylko wtedy, gdy cesarz je zatwierdzi ${ }^{10}$. Euzebiusz chwali cesarza, że mimo iż był faktycznym zwierzchnikiem biskupów, łaskawie uważał się za jednego z nich, choć to on ich zwoływał i przewodniczył ich obradom ${ }^{11}$. Nie była to tylko opinia zachwyconego Euzebiusza. Również na Zachodzie w kilkadziesiąt lat później pisał Ambrozjaster, że władza cesarza nad biskupami jest analogiczna do władzy Boga Ojca nad Chrystusem ${ }^{12}$. Konsekwentnie, jak Chrystus był posłuszny Ojcu, tak biskupi winni być posłuszni cesarzowi.

Kościelne zmartwienia Konstantyna wylicza Euzebiusz. W Vita Constantini pisze zarówno o sporze między Aleksandrem i Ariuszem oraz o schizmie melicjańskiej $^{13}$, jak i o nierozstrzygniętej jeszcze kwestii daty Wielkanocy ${ }^{14}$. Warto zauważyć, jak w tym miejscu rozkłada akcenty. Otóż kontrowersji pomiędzy obu duchownymi poświęca jedną linijkę, schizmie jedno zdanie, dacie Wielkanocy zaś cały rozdział. Taka zatem była widocznie jego hierarchia ważności. Czy podobnie myślał cesarz?

Sprawa schizmy melicjańskiej była niewątpliwie poważna, gdyż dotyczyła jedności Kościoła. Niejaki Melicjusz z Likopolis, w czasie prześladowań w latach 303-312 stanął na czele rygorystów, którzy uważali, że niegodni piastowania urzędów w Kościele są nie tylko ci, którzy się zaparli wiary, ale również tacy, którzy przed prześladowaniami uciekli. Mianował więc „swoich” biskupów i prezbiterów na opróżnione stolice, zajmując z rozpędu również te, których biskupi byli w więzieniach. Powstał więc w Egipcie i Libii jakby równoległy, schizmatycki Kościół.

Nasz list, jak zobaczymy za chwilę, zdaje się łączyć kwestię schizmy ze sporem doktrynalnym. Pewnym potwierdzeniem tego może być relacja Sozomena ${ }^{15}$, który zwykle przepisywał od starszego kolegi Sokratesa, tu jednak zdaje się mieć własne i bardziej kompletne źródła. Pisze on mianowicie, że Ariusz wspierał biskupa Melicjusza w jego sporach z prawowitym biskupem Piotrem, jeszcze przed rokiem 311. Potem miał się pojednać z Piotrem, uzyskać od niego święcenia diakonatu i znowu wejść z nim w konflikt z powodu popierania zwolenników Melicjusza. Wydaje się jednak wątpliwe, by jego sympatie melicjańskie miały być jeszcze aktualne w czasach biskupa Aleksandra, gdyż zapewne wypomniano by mu to, jako dodatkową okoliczność obciązającą.

Nim zajmiemy się sprawą Ariusza zwróćmy jeszcze uwagę na kwestię daty Wielkanocy i powodom, dla których tak ważną dla cesarza sprawą było jej ustalenie. Przypomnijmy sobie, że problem ten towarzyszył Kościołowi od daw-

${ }^{10}$ Por. Vita Constantini IV 27.

11 Por. tamże I 44.

12 Por. Quaestiones Veteris et Novi Testamenti 35 i 110 (Pseudo-Augustinus), CSEL 50, 63 i 269; por. Farina, L'Impero, s. 247.

${ }^{13}$ Por. Vita Constantini II 61-62.

14 Por. tamże III 5 .

15 Por. Sozomenus, HE I 15. 
na. Istniały bowiem od zarania dwie na ten temat tradycje. Judeochrześcijanie nie widzieli żadnego powodu, by obchodzić ją w innych dzień, niż ten wyznaczony przez żydowski kalendarz, czyli 14 dnia miesiąca Nisan, bez względu na dzień tygodnia. Etnochrześcijanie, czyli wierni pochodzący z innych narodów, obchodzili Wielkanoc w niedzielę po tej dacie, czyli po pierwszej pełni wiosennej, na pamiątkę Chrystusowego zmartwychwstania „po szabacie”"16. Już w II wieku papiez Wiktor chciał przekonać Azjatów do świętowania Wielkanocy w niedzielę, nawet w tej sprawie jeździł do niego biskup Polikarp ze Smyrny, nie ustalono jednak niczego, choć rozstano się pokojowo. Również Ireneusz bronił prawomocności praktyki wschodniej. Pomijając wspólnoty judeochrześcijańskie, ustaliło się w Kościele, że biskup Aleksandrii informował cały świat chrześcijański o dacie Wielkanocy na dany rok; widocznie miano zaufanie do egipskich astronomów. Na początku IV wieku problem jednak był już innej natury. Judeochrześcijanie jeszcze oczywiście istnieli, ale byli taką mniejszością, że mogło to cesarzowi snu z oczu nie spędzać. Ważniejsze było, że co do tej daty nie mogły się porozumieć również najważniejsze stolice chrześcijaństwa, to znaczy Aleksandria i Rzym. W Egipcie obliczano Paschę jak umiano, nie przejmując się tym, że wypada czasem po 21 kwietnia. W Rzymie było to zaś nie do przyjęcia: od tego dnia, jako rocznicy założenia Miasta, liczono czasem początek roku. Jeśli więc kiedyś miałaby Wielkanoc wypaść po tej dacie, jeden rok byłby w ogóle bez Wielkanocy, w drugim zaś byłyby dwie. Cesarz pisał po soborze do wszystkich Kościołów: „Nigdy przecież nie znieślibyśmy tego, żeby w jednym roku dwa razy urządzać święto Paschy!"17. Dotyczyło to także Paschy judeochrześcijańskiej, gdyż i ta mogła wypaść przed lub po 21 kwietnia, a czasem wręcz przed wiosennym zrównaniem dnia z nocą, gdyż Żydzi nie opierali się na obserwacjach astronomicznych, ale na ustalonym kalendarzu księżycowym, który miał 12 miesięcy po 29 i pół dnia, więc co trzy lata dodawano do roku nowy miesiąc księżycowy, by zrównać się ze słonecznym. Powodowało to, że 14 dzień księżycowego miesiąca Nisan, w którym Żydzi mieli obchodzić Paschę, czasem mógł wypaść przed równonocą ${ }^{18}$.

Zauważmy, że Kościół w miarę spokojnie egzystował mimo takich różnic. Cesarz jednak nie mógł na to przystać. Z urzędu był on najwyższym pontyfikiem i do jego obowiązków należało ustalanie kalendarza dni świątecznych dla wszystkich religii ${ }^{19}$. Tak w 321 roku ustanowił niedzielę dniem wolnym od

${ }^{16}$ Na temat skomplikowanych obliczeń dnia Paschy por. J. Naumowicz, Geneza chrześcijańskiej rachuby lat, Kraków 2000, 82-87 (Obliczenia chrześcijańskie).

17 Epistola Constantini Augusti ad universas Ecclesias, w: Socrates, HE I 9, PG 67, 92, thum. Kazikowski, s. 46.

18 Por. Naumowicz, Geneza, s. 91-99; D. Vigne, Une Église, plusieurs dates de Pâques?, BLE 102 (2001) 250.

19 Por. J. Guillen, Urbs Roma. Vida y costumbres de los Romanos, III, Salamanca 1980, 303nn; zob. Titus Livius, Ab urbe condita I 20. 
pracy $^{20}$, a nawet sam ułożył modlitwę do odmawiania przez legionistów ${ }^{21}$. Chciał także, a wręcz musiał, ustanowić dzień obchodzenia Wielkanocy w całym państwie, by rzeczywiście było to święto doroczne. Próbował do ustalenia tej daty nakłonić już zebranych przez siebie biskupów na synodzie w Arles w 314 r., ci jednak niczego konkretnego w tej materii nie postanowili, a jedynie wyrazili wolę, by wszystkie Kościoły obchodziły Wielkanoc w tym samym dniu ${ }^{22}$.

Bezpośrednim powodem napisania listu było zaniepokojenie cesarza sporem biskupa z Ariuszem w Aleksandrii, który zataczał coraz szersze kręgi. Jako że jednak nie o arianizmie chcę pisać, a o samym liście, pozwolę sobie tylko krótko naszkicować dotychczasowy przebieg kontrowersji. Otóż razu pewnego doszło do publicznego sporu między biskupem Aleksandrii a księdzem Ariuszem na temat interpretacji jakiegoś fragmentu Pisma Świętego. Wynikło z niego, że Ariusz nie uznaje boskiej natury Syna Bożego, Logosu, takiej jak Ojcowska, ale traktuje Go jako najdoskonalsze stworzenie Boże, uczynione z niczego ${ }^{23}$. Aleksander wykluczył z Kościoła Ariusza i jego zwolenników na synodzie, chyba nie później niż w 323 roku i specjalnym listem okólnym poinformował o tym „,wszystkich” biskupów ${ }^{24}$. Ariusza wziął w obronę Euzebiusz z Nikomedii i również pisał w tej sprawie do „wszystkich” biskupów. Spór stał się więc domeną publiczną, przynajmniej na całym Wschodzie, i stąd interwencja cesarza. Przejdźmy już jednak do samego Listu:

\section{List Konstantyna do biskupa Aleksandra i Ariusza prezbitera ${ }^{25}$}

(64) Konstantyn Zwycięzca, Największy August ${ }^{26}$ do Aleksandra i Ariusza.

Czynię świadkiem Boga, moją Pomoc we wszystkich przedsięwzięciach, Zbawcę wszystkich ludzi, iz dwie byty przyczyny, dla których podjąłem obowiązek teraz wypetniany.

20 Por. CJ III 12, 2.

21 Por. Vita Constantini IV 19-20.

22 Por. Concilium Arelatense (314), can. 1, SCL 1, 71; zob. A. di Berardino, L'imperatore Costantino e la celebrazione della Pasqua, w: Costantino il Grande dall'antichità all'umanesimo. Colloquio sul Cristianesimo nel mondo antico (Macerata, 18-20 dicembre 1990), I, red. G. Bonamente - F. Fusco, Macerata 1992, 364nn.

${ }^{23} \mathrm{Na}$ ten temat zob. mój artykuł: Początek „kontrowersji ariańskiej”, w: Chrześcijaństwo antyczne, red. J. Drabina (= „Studia Religiologica UJ”z. 35), Kraków 2006, 57-79.

${ }^{24}$ Por. Epistula Alexandri ad omnes episcopos, w: Socrates, HE I 6, Opitz III/1, 6-10, thum. S. Kazikowski - A. Caba, SCL 1, 78-82.

${ }^{25}$ Epistola Constantini ad Alexandrum episcopum at Arium presbyterum, w: Eusebius, Vita Constantini II 64-72, PG 20, 1037-1048; ed. J.A. Heikel - F. Winkelmann, GCS 7a, 74-79; oddzielne wydanie krytyczne w: Opitz III/1, Urk. nr 17, 32-35, tłum. T. Wnętrzak. Cyfry 64-72 oznaczają rozdziały listu w Vita Constantini, wyd. H. Opitza ma inny podział listu (1-15).

${ }^{26}$ Na temat tytułów cesarskich zob. Sokrates Scholastyk, Historia Kościoła, tłum. S. Kazikowski, Warszawa 1972, s. 24, nota 34, lub wyd. 2, wstęp E. Wipszycka, komentarz A. Ziółkowski, Warszawa 1986, s. 72, nota 45. 
(65) Było moim goracym pragnieniem, po pierwsze sądy formułowane przez wszystkie narody, odnoszące się do Bóstwa, ujednolicić i uczynić jakby jednym systemem oraz, po drugie, przywrócić zdrowie organizmowi całego świata, cierpiacemu złowroga tyranię jakby bolesna chorobę.

Wygląda z tego, jakoby cesarz okazywał zamiar jakiegoś ujednolicenia wiary w Boga we wszystkich religiach cesarstwa. Być może wydawało mu się, że zaprowadzi pokój religijny, w którym wszystkie religie znajdą swoje miejsce i wszystkie będą współdziałać dla ogólnego dobra. Tak właśnie była postrzegana rola najwyższego pontyfika i całego kolegium pontyfików: mieli czuwać nad harmonią religii w ramach państwa. Cesarz swą pontyfikalną władzą objął chrześcijaństwo i dlatego wypada nam przyjrzeć się bliżej jego obowiązkom. Wiemy o tym przede wszystkim od Cycerona i Liwiusza.

Urząd najwyższego pontyfika i jego kolegium istniał w Rzymie od czasów niepamiętnych. Wiadomo tylko, że już w 300 r. przed Chrystusem został zreformowany tak zwaną lex ogulnia. Liwiusz, starożytny autor historii Rzymu, pisze o tej reformie dokonanej przez króla Numę:

Mianował najwyższego pontyfika Numę Marcjusza, jednego z senatorów i jemu powierzył szczegółowy spis i opis całej służby bożej: jakie zwierzęta, w których dniach i przy których świątyniach ma się składać w ofierze i skąd brać na nie pieniądze. Podobnie wszystkie inne sprawy religijne, tak w zakresie publicznego, jak i prywatnego życia, oddał do jego decyzji. Do niego miał się lud udawać po poradę, aby przez zaniedbywanie obrzędów ojczystych, a przyjmowanie obcych nie wkradło się do służby bożej jakieś zamieszanie. Zresztą, nie tylko czci niebian miał uczyć najwyższy pontyfik, ale i tego, jak należy urządzać pogrzeby i przebłagania słać duchom zmarłych, jakie znaki cudowne, czy to pioruny, czy inne znaki widzialne, uważać za ważne i jak je zażegnywaće ${ }^{27}$.

Według zaś świadectwa Cycerona, żyjącego jeszcze w czasach rzeczpospolitej rzymskiej, czyli nim cesarze zawłaszczyli urząd pontyfika, do kompetencji kolegium pontyfikalnego liczącego 19 członków, należały sprawy de sacris, de votis, de feriis i de sepulchris ${ }^{28}$. De sacris znaczyło pilnowanie, by wszystkie przepisane modlitwy były odmawiane dokładnie; publicznie spontaniczność w tym względzie była wykluczona, choć dopuszczalna prywatnie. Pilnowano też składania ofiar „w czystości”, co dotyczyło przede wszystkim czystości seksualnej, w zależności od wymogów poszczególnych kultów, ale rozciągało się także i na ogólne prowadzenie się kapłana. Na mocy kompetencji de votis pontyfikowie określali stosowne formuły ślubów na różne okoliczności, a także mogli ze ślubów zwalniać. De feriis było faktycznie władzą nad kalendarzem. T.

27 Titus Livius, Ab urbe condita I 20, tłum. A. Kościółek, oprac. M. Brożek - J. Wolski: Liwiusz Tytus, Dzieje Rzymu od założenia miasta, I, Wroclaw 1968; por. też H. Kowalski, Pontifex Maximus w religii i państwie rzymskim, VoxP 24 (2004) t. 46-47, 19-31.

${ }^{28}$ Por. Cicero, De legibus II 47. 
Zieliński podsumowuje: „Pontyfikowie byli nie tyle kapłanami danego bóstwa, ile rzeczoznawcami i doradcami w sprawach religijnych w ogóle" ${ }^{29}$. W sposób szczególny podlegały mu westalki, przy domu których mieszkał. Podporządkował się temu także Juliusz Cezar, kiedy został wybrany na najwyższego pontyfika; wtedy też dopiero mógł pozwolić sobie na zreformowanie kalendarza, gdyż żaden inny urząd by mu na to nie pozwolił w przywiązanym do tradycji Rzymie. Oktawian August został wybrany na to stanowisko (godność?) dopiero w 12 r. (p. Chr.) po niejakim Lepidzie, któremu udało się zawładnąć tytułem po śmierci Cezara; dopiero wtedy też mógł wprowadzić poprawki do kalendarza świąt i obsadzić wakujące stanowiska kapłańskie. Pozostał też wierny tradycji mieszkania przy westalkach, tyle, że nie on się wprowadzil do nich, a one do niego: zabrał je do nowej rezydencji na Palatynie. Od tego czasu najwyższym pontyfikiem mianowano każdego cesarza aż do roku 379 , kiedy to zachodni cesarz Gracjan z tego tytułu zrezygnował, a nowo wybrany cesarz Wschodu, Teodozjusz, w ogóle go nie przyjął. Dla kompletności obrazu trzeba też zauważyć, że w praktyce rezygnacja $\mathrm{z}$ tytułu pontyfika nie oznaczała bynajmniej - w przypadku cesarzy bizantyńskich - rezygnacji z ich kompetencji. Cesarz Konstantyn również musiał się z tych obowiązków wywiązać i zależało mu na tym, by ustanowić jakieś formuły wiary chrześcijańskiej, wszystkich obowiązujące.

(65 cd.) Skoro postawitem sobie te zadania, jedno staratem się wypetniać sekretnym okiem myśli, drugi zaś cel osiągną́ potęgą sily militarnej. Bytem bowiem świadomy, ze jeśli uzyskałbym sukces $w$ dziele ustanowienia, według moich nadziei, powszechnej harmonii i zgody pomiędzy wszystkimi sługami Boga, to wówczas i ogót spraw państwowych doznałby korzystnej zmiany pod wpływem pobożnych życzeń ptynacych od nich wszystkich.

Według rzymskiej mentalności sprawy religijne były nierozdzielnie związane z publiczno-państwowymi. Do cywilno-religijnej liturgii należało jednakowo załatwianie spraw urzędowych, jak składanie publicznych ofiar bogom, bowiem ich przychylność rozumiano jako nieodzowną w dobrym funkcjonowaniu państwa.

(66) Przeto gdy cała Afrykę opanowało nieznośne szalenstwo pod wptywem tych, którzy przez nieostrożna lekkomyślność odważyli się rozerwać religię ludu na różne sekty, ja, chcac powstrzymać chorobę, uznatem, że nie pomoże w tej sprawie żadne inne lekarstwo, jak tylko to: wysłatem niektórych spośród was, aby pomogli w odbudowaniu wzajemnej harmonii i zgody miedzy uczestnikami sporu, po tym, jak wcześniej usunąłem wspólnego wroga rodzaju ludzkiego, który bezprawnym

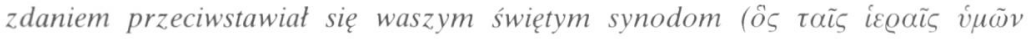

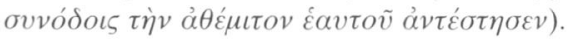

29 T. Zieliński, Religia Rzeczypospolitej Rzymskiej, cz. 2, Kraków 1933, 33. 
"Wrogiem rodzaju ludzkiego" miałby być według powszechnej opinii Licyniusz $^{30}$. O tym, że zakazywał on zwoływania synodów informuje nas Euzebiusz $^{31}$. Co do sekt, to rzecz dotyczy zapewne - między innymi - problemów z donatyzmem w Afryce, które cesarz starał się już wcześniej rozwiązać na zwoływanych w tym celu synodach w Rzymie (313) i w Arles (314). Mielibyśmy jednak wielką niezgodność chronologiczną, gdyż donatyzm rozkwitł po 312 r., a nie dopiero po usunięciu Licyniusza w 324 roku. Nie można więc wykluczyć, że chodzi tu raczej o cesarza Maksymina Daję, o którym Euzebiusz pisał: „wróg tego, co zacne, i nieprzyjaciel wszystkiego, co dobre” ${ }^{32}$ i który zakazał chrześcijanom zebrań (synodos) na cmentarzach. Po zwycięstwie nad Maksyminem Konstantyn rzeczywiście też ingerował kilkakrotnie w spory afrykańskie; dossier wydanych przez niego dokumentów na ten temat podaje Euzebiusz $^{33}$. Doręczycielami tych listów byli zapewne jacyś duchowni, jak w przypadku niniejszego listu - Hozjusz. Konstantyn więc zdaje się tym przypomnieniem podkreślać, że pisze w prawie i że dawniej też tak postępował, gdy zaistniała potrzeba. Dla porządku przypomnijmy, że Egipt w administracyjnym podziale cesarstwa nie zaliczał się do Afryki.

(67) Ponieważ potęga Boskiego światła i prawo świętej wiary, dzięki dobroci Bożej, wydane zostaty, rzec można, z tona Wschodu, po czym ogarnęty święta jasnościa jednocześnie cały świat, stusznie wierzą, że wy będziecie pierwszymi, którzy dadza początek zbawieniu innych narodów, spróbowatem energia myśli i siła spojrzenia poszukać waszej pomocy. Albowiem zaraz po wielkim zwycięstwie i niekwestionowanym triumfie nad wrogami, postanowitem przede wszystkim zbadać to, co jak sądzitem, jest najwyższej wagi i najcenniejsze ze wszystkiego.

(68) Lecz, o najwspanialsza Opatrzności Boża, jak ciężko i jak głęboko zranione zostały nie tylko moje uszy, lecz i samo serce, gdy przyniesiono mi wiadomość, że powstata miedzy wami niezgoda jest o wiele cięższa od tej, która trwa nadal w tamtym kraju [tzn. w Afryce]! Przeto wy, z pomoca których miatem nadzieję dostarczyć lekarstwo na btędy innych, sami znajdujecie się w stanie wymagajacym leczenia w stopniu powazniejszym niż drudzy. Kiedy zastanawiatem się nad początkiem i przedmiotem tych różnic, stawato się dla mnie widoczne, że przyczyna sporów ma charakter o naprawdę niewielkim znaczeniu i jest zupełnie niegodna takiej zapalczywości. Przekonany o konieczności zwrócenia się do was w tym liście i zaapelowania o wasza jednomyślność i roztropność, wzywam Boska Opatrzność, by pomogła mi w tym zadaniu, bym jako moderator pokoju przerwat wreszcie wasze wzajemne pretensje. Choćby nawet powazniejsza była okoliczność niezgody, to jednak, z pomoca większej Potęgi, bez trudności byłbym w stanie, przyjmując rację pobożnych opinii tych, którzy mnie stuchaja, naktonić każdego do bardziej pożytecznych przekonań. Obecnie, gdy daleko mniejsza i naprawdę nieznacząca

\footnotetext{
${ }^{30}$ Por. np. J.L. Maier, Le dossier du donatisme, I, Berlin 1987, 244.

31 Por. Vita Constantini I 51.

${ }^{32}$ HE IX 2, PG 20, 801-804, POK 3, 395

33 Por. HE X 5-6, PG 20, 880-893.
} 
jest przyczyna sporu, będaca przeszkodą dla zgodnej harmonii całego ciała, dlaczego nie miatbym się starać o naprawę tej rzeczy, co jest i tatwiejsze i o wiele prostsze?

Tenor słów cesarza zdaje się wskazywać, że z poważniejszymi już problemami sobie radził i wielu ludzi potrafił przywołać do porządku, tym łatwiej więc powinno mu pójść tym razem. Co prawda bowiem, sprawa się rozdęła, jednak przyczyna jej zaistnienia jest błaha. Wydaje się, że wspominany wyżej problem Kościoła afrykańskiego, czyli donatyzm, w opinii cesarza był poważniejszy, niż spór między Aleksandrem a Ariuszem.

$(69)^{34}$ Rozumiem, że zaistnienie obecnej kontrowersji takie miało pochodzenie i początek: Kiedy ty, Aleksandrze, zapytałeś swoich prezbiterów, jaka jest opinia każdego z nich na temat pewnego ustępu w tekście Boskiego prawa, czy, jak powinienem raczej powiedzieć, dowiadywałeś się o jakieś elementy kwestii jatowej i bezużytecznej, wtedy ty, Ariuszu, nierozważnie wydobyteś coś, co nigdy nie powinno być rozważane, a jeśli już stało się przedmiotem rozważań, powinno być powierzone milczeniu. Stąd powstała między wami niezgoda, wspólnota została wypowiedziana, zaś najświętszy lud, podzielony na dwie części, odszedt od zgody i przestał być jednościa wspólnego ciała. Zatem jeden i drugi $z$ was niech okaze wzajemna wyrozumiałość i przyjmie radę, jakiej stusznie udziela wam wasz wspótstuga.

Komentator polskiego wydania, Adam Ziółkowski, nie ma wątpliwości, że chodziło o tekst Prz 8, 22-25, w którym Mądrość mówi o sobie: „Od początku i przed wiekami jestem stworzona”, oraz „Przed pagórkami jestem rodzona”. O stworzenie zatem i zrodzenie Syna Bożego miałby toczyć się spór ${ }^{35}$. Podobnie pisze Manlio Simonetii w swej monumentalnej pracy o arianizmie ${ }^{36}$, Charles Pietri ${ }^{37}$ i wielu innych. Pragnę jednak zaznaczyć, że nie jest to oczywiste. Nie wiemy, czego dotyczył spór. Na pewno jednak w wielu kwestiach musiała występować różnica poglądów między Ariuszem, a Aleksandrem i innymi prezbiterami Aleksandrii, gdyż różnili się oni wykształceniem. Ariusz był prawdopodobnie uczniem Lucjana z Antiochii i kolegą szkolnym między innymi Euzebiusza z Nikomedii. Właściwe dla Antiochii „oddolne” podchodzenie do chrystologii, to znaczy podkreślanie najpierw Chrystusowego człowieczeństwa, a potem dopiero bóstwa, różniło się fundamentalnie od myślenia aleksandryjskiego, w którym ważne było przede wszystkim to, że Chrystus jest

${ }^{34}$ Od tego miejsca cytuje list Sokrates (HE I 7). Pisze on już po upływie ponad stu lat i, według niego, Sobór Nicejski miał przede wszystkim charakter antyariański. Nie interesuje go więc pierwsza część listu.

${ }^{35}$ Por. Socrates, HE I 7, thum. S. Kazikowski, wyd. 2, wstęp E. Wipszycka, komentarz A. Ziółkowski, Warszawa 1986, s. 72, nota 46.

36 Por. La crisi ariana, Roma 1975, 35.

37 Por. Constantin et christianisation de l'empire, w: Histoire du christianisme des origines à nos jours, dir. J.M. Mayeur - Ch. et L. Pietri - A. Vauches - M. Venard, II, Paris 1995, 263. 
Logosem Boga, a na drugim to, że stał się człowiekiem. Jest to tylko różnica metody, ma jednak swoje reperkusje. Konstantyn nazywa się współsługą biskupa i prezbitera na mocy swojej władzy najwyższego pontyfika, jak widzieliśmy już powyżej.

(69 cd.) Jaka jest więc ta rada? Ani na samym początku nie należato pytać o sprawy tego rodzaju, ani później odpowiadać, gdy pytania zostaty postawione. Albowiem takie właśnie kwestie, których nie nakazuje autorytet żadnego prawa, ale podsuwa raczej swarliwość karmiona niewłaściwym korzystaniem z wolnego czasu, choćby powstawaty jako czysto intelektualne ćwiczenia, to jednak powinny być zamknięte tylko w obszarze naszych myśli i nie należy pochopnie wynosić ich na zgromadzenia publiczne i nieroztropnie powierzać uszom ludu.

Zwraca uwagę rzymska mentalność cesarza: ważne jest to, co jest określone przez prawo. Dyskusje na tematy doktrynalne nie były prawnie regulowane, nie powinny więc mieć znaczenia w wymiarze państwowym czy społecznym. Ich upowszechnianie wśród ludzi prostych jest niewłaściwe, gdyż burzy spokój i ład. W tym kontekście wydaje się być ważne, że Konstantyn był obeznany z religiami misteryjnymi, w których ważne były stopnie wtajemniczenia: nie wolno było ich przekraczać.

(69 cd.) Jakże jest przecieź niewielu, którzy są w stanie czy to dokładnie zrozumieć czy właściwie wyttumaczyć rzeczy tak bardzo wznioste i z natury niejasne? Jeśli zaś ktoś uważatby, ze z tatwościa może to uczynić, jak wielka czesść ludu przekona? Albo kto, obcując z kwestiami o takiej subtelności i finezji jak te, może uchronić się od niebezpieczeństwa rozminięcia się z prawda??

Przekonanie o tym, że wiedza na temat spraw boskich przewyższa możliwości mędrców, a jeśliby nawet ją zdobyli, nie powinni się z nią dzielić z innymi, gdyż nie zostaną zrozumiani, sformułował Platon między innymi takimi słowy: "Najwyższe dobro nie jest rzeczą dającą się ująć słowami; lecz z długotrwałego obcowania z nim, nagle, jakby pod wpływem przebiegającej iskry, zapala się w duszy światło”, 38 a jeszcze klarowniej tak: „Trudno jest znaleźć twórcę i ojca tego wszechświata, a znalazłszy mówić o nim do wszystkich - niepodobna"39, co cytuje Celsus w swym dziele Prawdziwe słowo, napisanym przeciwko chrześcijanom, a polemizuje $\mathrm{z}$ nim Orygenes w Przeciw Celsusowi ${ }^{40}$. Konstantyn wykazuje się więc znajomością klasyki i zdaje się podzielać pogląd Platona. Wynika z tego, że nie uważa za stosowne, by z subtelności teologicznych czynić sprawę publiczną.

${ }^{38}$ Plato, Epistolae 7, p. 341CD, tłum. M. Maykowska, cytuję za: Orygenes, Przeciw Celsusowi VI 3, thum. S. Kalinkowski, Warszawa 1986, s. 288, nota 4.

${ }^{39}$ Plato, Timaios 5, p. 28C, tłum. W. Witwicki: Platon, Dialogi, II, Kęty 1999, 677.

40 Por. Origenes, Contra Celsum VII 42. 
(69 cd.) W takich kwestiach obowiazkiem naszym jest powściaganie wielomówstwa, aby, w przypadku, gdy my sami nie potrafimy, z powodu stabości naszych zdolności naturalnych, udzielić jasnego wyttumaczenia postawionego przed nami zagadnienia, albo, $z$ drugiej strony, w przypadku, gdy powolność rozumowania naszych stuchaczy uniemożliwia im dotarcie do dokładnego zrozumienia tego, co mówimy, z jednej więc lub drugiej przyczyny lud nie był przywiedziony do konieczności wyboru pomiędzy bluźnierstwem a schizmą.

(70) Zatem niech zarówno nieostrożne zapytanie, jak i nierozważna odpowiedź otrzymajq wasze wzajemne wybaczenie. Albowiem przyczyna waszej niezgody nie była ani główna doktryna czy przepis Boskiego prawa, ani nie powstała między wami jakaś nowa herezja odnosząca się do kultu Boga. Obaj jesteście jednego i tego samego zdania, przeto z łatwością możecie połączyć się w zgodnej wspólnocie.

(71) Skoro wy toczycie ze soba spór o rzeczy mate i naprawdę nieistotne, jest niestosowne, że tak wielka czesść ludu Bożego jest kierowana według waszych osadów, kiedy trwacie $w$ niezgodzie. Jestem przekonany, ze jest to nie tylko niewłaściwe, lecz po prostu złe.

Zdaniem cesarza, powód sporu jest bez znaczenia dla jedności Kościoła, nie dotyka żadnego przepisu prawa ani należnej czci Bogu. Wszyscy znani mi komentatorzy tego tekstu podkreślają, że nadanie tak marnej rangi przedmiotowi sporu przez Konstantyna jest spowodowane jego ignorancją na temat chrześcijaństwa. Nie zdawał sobie jakoby sprawy, że w chrześcijaństwie nie jest ważny jedynie kult i normujące go przepisy prawne, jak w religiach tradycyjnych, ale przede wszystkim doktryna (ortodoksja) objawiona przez Boga i wymagająca interpretacji. Takie wyjaśnienie ma sens przy założeniu, że kontrowersja między Aleksandrem a Ariuszem była tak ważna, że aż w jej sprawie zwołano Sobór. Pozostańmy raczej przy tym, że Konstantyn rzeczywiście uważa ten spór za mało ważny. Ważną przy tym okolicznością jest fakt, że cesarz zna sprawę z drugiej ręki. W Nikomedii bowiem informował go prawdopodobnie Euzebiusz z Nikomedii, teolog niewątpliwie wykształcony, oraz biskup Hozjusz, który cieszył się zaufaniem cesarza do tego stopnia, ze jego właśnie wysłał z misją na Wschód, by spotkał się również z Aleksandrem i Ariuszem. To więc na ich zdaniu musiała - do znalezienia dowodów przeciwnych - opierać się opinia cesarza. Uważam zatem za rozsądne przyjąć, że taka akurat była opinia na temat sporu na dworze cesarskim, z uwzględnieniem zdania obu biskupów rezydujących w stolicy, a nie tylko osobiste zdanie Konstantyna. Trzeba nam także zaznaczyć, że nic nie wiemy o rodzaju wzajemnej znajomości Euzebiusza i Hozjusza, czy lubili się, czy nie, czy konkurowali z sobą o względy cesarza, czy też współdziałali.

(71 cd.) Lecz ja obudzę wasze umysty upomnieniem, przywotując maty przykład, który jest następujący. Wiecie, że sami filozofowie, chociaż wszyscy sa potaczeni przynależnościq do jednego systemu, często jednak spieraja się w pewnych punktach twierdzeń. I pomimo, że różnia się co do stopnia doskonałości swojej wiedzy, 
znowu powracaja do wzajemnej zgody dzięki jednoczacej sile ich wspólnej doktryny. Jeśli więc to jest prawda, czyż nie jest daleko bardziej słuszne, byście wy, ustanowieni sługami Najwyższego Boga, byli między soba tego samego ducha w odniesieniu do wyznawania tej samej religii?

Zdaniem cesarza, a więc również - jak podejrzewam - Euzebiusza i Hozjusza, którzy mu doradzali, różnica w poglądach nie powinna naruszać jedności Kościoła, tak jak dyskusje w ramach szkoły filozoficznej nie muszą powodować jej podziału; wręcz przeciwnie, świadczą o jej żywotności, jeśli służą poszukiwaniu prawdy, a nie są wynikiem przerostów ambicjonalnych. Konstantyn traktuje doktrynę chrześcijańską jak filozofię jednej szkoły, w której różnice zdań są sprawą wewnętrzną. Między poszczególnymi szkołami dyskusje były innego rodzaju, takie jakie opisywał kilkadziesiąt lat wcześniej Grzegorz Cudotwórca w Mowie na cześć Orygenesa:

Sprzeczne i zwalczające się wzajemnie nauki są właśnie przyczyną sporów między filozofami. Jedni zwalczają twierdzenia innych, jedni bronią jednego, inni innego stanowiska $[\ldots]$ nie chcą słuchać nikogo, kto głosi poglądy inne niz oni ${ }^{41}$.

Ostatnie zdanie świadczy o tym, że Konstantyn jednak nie traktuje chrześcijańskich dysput po prostu jako filozoficznej wymiany poglądów. Widzi różnice: wartością naczelną dla niego jest jednak służba Bogu, ważniejsza od różnic.

(71 cd.) Lecz jeszcze głębiej się zastanówmy $i$ z większą uwaga zbadajmy to, co powiedziałem, zobaczmy, czy to jest dobre, ze, z powodu waszego sporu o błaha i głupia różnicę słów, bracia staja naprzeciw siebie jako wrogowie i że czcigodny synod (snodoj t...mioj) został rozdarty profanującym podziałem z powodu was, którzy kłócicie się ze sobą o sprawę tak trywialną $i$ zupetnie niepotrzebna. Takie postępowanie cechuje raczej pospólstwo albo pasuje do nierozumności młodzieńczej i nie przystoi zupetnie mądrości kaptanów i męzów rozumu. Sami, z dobrej woli, odsuńmy się od tych pokus diabła. Nasz wielki Bóg, wspólny zbawca każdego, udzielit tego samego światła wszystkim.

„Synod” odnosi się tutaj raczej do Kościoła jako zgromadzenia, które winno trwać w zgodzie, a nie do konkretnego synodu w znaczeniu zebrania biskupów. Cesarz porównuje przedmiot sporu jako rzecz bez większego znaczenia, a sam spór jako niegodny poważnych ludzi. Skoro tak to widział, wydaje mi się rzeczą nieprawdopodobną, by w tej sprawie zamierzał zwoływać wszystkich biskupów.

(71 cd.) Pozwólcie, abym ja, który jestem stuga Wszechmocnego, z pomoca Jego Opatrzności, doprowadzit to zadanie do pomyślnego rezultatu, bym przez moje przemowy, moja stużbę i gorliwość w upomnieniach przywiódt was, Jego lud do zespolenia i jedności. Skoro więc, jak już powiedziałem, wyznajecie jedna wiarę i macie jedno myślenie o naszej religii, skoro przepis Boskiego prawa we wszystkich

${ }^{41}$ In Origenem oratio panegyrica 158-159, SCh 148, 160-162, thum. S. Kalinkowski, ŹMT 11, 71-72. 
swoich częściach zmusza do okazywania jednego ducha, niech okoliczności, które wywołuja między wami niewielka niezgodę, chociaż nie wpływaja na siłę całej religii, nie powodują wśród was podziału i kłótni. I mówię to zupetnie bez chęci zmuszenia was do tego, abyście osiągnęli catkowita jedność sądu co do tej kwestii naprawdę jałowej, jakakolwiek byłaby jej natura. Albowiem może być zachowana catkowicie powaga waszego synodu i pozostać nienaruszona powszechna jednomyślność, choćby nawet zaistniata między wami niezgoda w jakiejś rzeczy o nieistotnym znaczeniu, ponieważ nie chcemy tego samego wszyscy w odniesieniu do wszystkiego, ani nie rządzi nami jedna natura i jeden sposób myślenia. Natomiast co do Opatrzności Boskiej niech będzie wśród was jedna wiara i jedno rozumienie oraz jeden zgodny sad w odniesieniu do Boga.

Cesarz jako najwyższy pontyfik nie miał prawa ani obowiązku ujednolicania religii w Rzymie, ale winien dbać o wszystkie i szanować odrębności. Wydaje się, iż tę samą miarę Konstantyn przykłada do samego chrześcijaństwa i każe respektować odmienny sposób myślenia każdej ze stron. Pełnej zgody domaga się tylko w tym, co dotyczy Opatrzności Bożej. Trudno osądzić, czy pisząc o Opatrzności myślał to samo, co biskupi - jego doradcy. Pojęcie đœóvota było bowiem dobrze znane w Rzymie i bardzo ważne zarówno dla religii rzymskich, jak i dla sprawowania władzy. Świadczy o tym choćby imponujący spis 127 monet od Tyberiusza do Aleksandra Sewera z wyobrażeniem Prowidencji $^{42}$. Opatrzność stanowiła też podstawę systemu stoickiego, gdyż ogarniała wszelkie ciała, to znaczy wszelkie istnienie ${ }^{43}$. W świecie rzymskim podstawą swej teologii uczynił z niej Cyceron pisząc między innymi, że ,świat jest rządzony opatrznością bogów" "44. W III i IV wieku providentia łączy się z powodzeniem dynastii i z osiągnięciami militarnymi ${ }^{45}$. Kontekst analizowanego listu jest poniekąd militarny, gdyż - jak pamiętamy - cesarz wysyła go po zwycięstwie nad Licyniuszem, w momencie, w którym stoi wobec konieczności umocnienia swojej wyłącznej władzy nad Imperium. W tym celu nie może ryzykować igrania z Opatrznością, ale też ona jest dlań najważniejsza. Wszelkie inne kwestie religijne są w porównaniu z nią mało ważne.

(71 cd.) Co zaś do waszych subtelnych dysput w kwestiach małego lub żadnego znaczenia, chociaz nie dojdziecie do jednego i zgodnego ustalenia, trzeba, aby te róznice pozostały ukryte w sekretnych głębiach waszych myśli i serc. Teraz niech trwa wśród was niewzruszenie ta szczególna wartość wspólnoty i przyjaźni, wiara w prawdę, cześć dla Boga i zachowywanie Jego prawa. Powróćcie do wzajemnej przyjaźni i miłości, oddajcie całemu ludowi zwykłą wewnętrzna więź. Wy sami, po

42 Por. J.P. Martin, Providentia deorum. Aspects religieux du pouvoir romain, Rome 1982, 431-433.

${ }^{43}$ Por. Diogenes Laertios, Vitae philosophorum VII 1, tłum. W. Olszewski: Żywoty i poglądy stynnych filozofów, Warszawa 2004, 369-442 (Zenon); Anonymus, Philosophoumena 21, 1.

44 Cicero, De divinatione I 117.

45 Por. Martin, Providentia deorum, s. 428. 
oczyszczeniu swoich dusz, jeszcze raz postarajcie się siebie wzajemnie zrozumieć. Zdarza się bowiem często, ze po osiagnięciu pojednania przez odsunięcie przyczyn wrogości, przyjaźń staje się jeszcze słodsza, niż była wcześniej.

Zwraca uwagę, że cesarz ma nadzieję na pogodzenie się Aleksandra z Ariuszem i cały spór traktuje w kategoriach animozji nie mającej dostatecznych podstaw w samej rzeczy.

(72) Oddajcie mi w ten sposób moje dni bez zmartwień i noce wolne od trosk, aby rozkosz niezaćmionego światta i radość spokojnego życia mogły odtąd być znowu moim udziatem. Jeśli tak się nie stanie, trzeba będzie, abym jęczat w żalu, a cały zalewat się tzami i nie będę mógt spędzić reszty moich dni w pokoju. Albowiem jak długo lud Boży, a mówię o moich towarzyszach w stużbie Bogu, tak jest podzielony przez nieuzasadniona i szkodliwa niezgodę, czyż jest możliwe, abym mógt zachowywać jeszcze spokój ducha?

Cesarz nie wykazuje najmniejszego zamiaru podejmowania jakichś poważniejszych kroków w spornej sprawie, na przykład zwoływania synodu. Biorąc pod uwagę datę listu (jesień 324), szczegół ten wydaje mi się istotny. Wydaje się, że jest przekonany co do siły swojej perswazji.

(72 cd.) I oto dowód, abyście zrozumieli, jak wielki jest mój ból z tego powodu. Niedawno przybyłem do Nikomedii i zamierzatem z tego miasta natychmiast wyruszyć na Wschód. Kiedy spieszytem się do was i duchem prawie że bytem z wami, doniesienie o tej sprawie powstrzymało moje plany, ponieważ czutem, że bytbym zmuszony do ogladania własnymi oczami tego, o czym nie jestem w stanie nawet stuchać. Zatem od tej chwili otwórzcie mi, poprzez waszą zgodę, drogę do krain Wschodu, którą dla mnie zamknęliście przez wzajemne spory. Pozwólcie mi czym prędzej ujrzeć $i$ was samych $i$ wszystkich innych, caly lud we wspólnej radości oraz wypowiedzieć Wszechmocnemu należne stowa dziękczynienia i pochwaty za powszechna zgodę wszystkich i za wolność

Zdania te są dość dziwne: skoro spór dotyczył rzeczy mało ważnych, jak Konstantyn pisał wcześniej, dlaczego miałby z jego powodu odraczać planowaną podróż? Skądinąd też wiadomo, że taką podróż cesarz przedsięwziął w następnym roku, kiedy kontrowersja ariańska bynajmniej się nie skończyła; podróż zakończył w Rzymie triumfalnymi obchodami wieńczącymi vicenalia swoich rządów. Być może mamy tu do czynienia tylko z retoryczną przesadą.

Jak widzimy, list nie precyzuje, o co chodziło w sporze między biskupem i jego prezbiterem, ani w żaden sposób nie sprawia wrażenia, by jego autor słyszał o jakimś synodzie, na którym Ariusz zostałby ekskomunikowany. Trudno przypuścić, by cesarz pisał manu propria i propria mente. Zapewne tyle wiedział o sprawie, ile zakomunikowali mu jego doradcy, czyli przede wszystkim Hozjusz, ale i Euzebiusz z Nikomedii. Czyżby więc również oni ignorowali fakt przedsięwzięcia przez Aleksandra kroków dyscyplinarnych przeciw Ariu- 
szowi? Pozostaje faktem, że problemem dla cesarza był gorszący spór, burzący jedność Kościoła, a nie kwestie doktrynalne. Zawoalowana treść listu nasunęła nawet niektórym historykom myśl, że był on w rzeczywistości poświęcony sprawie donatyzmu, stanowiącego w Afryce ciągły problem i że skierowany był nie do Aleksandrii, a do Antiochii, na tamtejszy synod ${ }^{46}$. Dziwne jednak byłoby, gdyby Euzebiusz w biografii Konstantyna aż tak się pomylił, zwłaszcza, że w synodzie antiocheńskim wiosną 325 r. sam uczestniczył. A poza tym, gdzie Rzym, gdzie Krym - czemuż to do Antiochii miałby cesarz pisać o donatyzmie?

Cesarz jednak coś niewątpliwie miał na myśli wysyłając list, i to na dodatek przez posłańca o tak wysokiej randze. Nie mogło raczej chodzić o zwykłe doręczenie przesyłki, gdyż do tego mógłby posłużyć jakiś diakon.

W dalszym ciągu swego dzieła Euzebiusz pisze, że list cesarza nie odniósł żadnego skutku i że „zajadłość walczących stron nadal rosła” ${ }^{47}$, i to na całym Wschodzie. Pisze też, że konflikt powstały w Aleksandrii doprowadził do schizmy między Aleksandrią a Tebami, i że:

w każdym mieście biskupi popadali w zawzięty konflikt z biskupami, a ludzie powstawali przeciwko ludziom i, prawie jak mityczne Symplegady, nawzajem się zabijali. W szale przekraczali granice rozsądku, zachowując się nierozważnie i skandalicznie i doszło do tego, że ośmielali się znieważać wizerunki cesarza. Taki stan rzeczy nie wywoływał jego gniewu, lecz raczej smutek w duszy i bardzo bolał nad szaleństwem bezrozumnych ludzi ${ }^{48}$.

W dalszym ciągu pisze o problemach z ustaleniem daty Wielkanocy i konkluduje:

Gdy tylko został on [tzn. cesarz] zapoznany z faktami, które opisuję, i dowiedział się, że list wysłany przez niego do chrześcijan w Aleksandrii nie odniósł skutku, wzbudził w sobie energię i powiedział, że musi podjąć nową wojnę przeciwko ukrytemu wrogowi, który zakłóca pokój Kościoła ${ }^{49}$.

I wtedy zwołał sobór do Nicei. Euzebiusz pisał po śmierci Konstantyna, czyli 12 lat po interesujących nas wydarzeniach. Czy dobrze pamiętał wszystkie daty? Cóż to była za schizma między Aleksandrią a Tebami? Być może czyni aluzję do Lykopolis w Tebaidzie Pierwszej, czyli do stolicy biskupiej Melitiosa, chodziłoby więc o schizmę melicjańską. W związku z tym nasuwa się pytanie, czy mógł istnieć jakiś związek - w opinii Konstantyna i jego doradców - między schizmą melicjańską a sporem Aleksandra z Ariuszem? Gdyby tak było, można

${ }^{46}$ Por. S.G. Hall, Some Constantinian Documents in the Vita Constantini, w: Constantine. History, Historiography and Legend, ed. S.N.C. Lieu - D. Montserrat, London - New York 1998, 86-103.

47 Vita Constantini II 73.

48 Tamże III 4, GCS 7, 79 .

49 Tamże III 5, GCS 7, 79. 
by zrozumieć, że cesarz wzywa obu do zgody, gdyż nieporozumienie potęguje zamęt w Kościele spowodowany schizmą. Z relacji Euzebiusza zdaje się bowiem wynikać, że to schizma właśnie była dla cesarza największym problemem. Przypomnijmy też, że Hozjusz uczestniczył w Aleksandrii w synodzie, na którym omawiano tę właśnie sprawę $e^{50}$.

Sozomen informuje nas ${ }^{51}$, że Ariusz miał kontakty z Melicjanem za czasów biskupa Piotra. Porzucił go jednak i przez Piotra został ustanowiony diakonem. Później miał krytykować biskupa za postanowienia antymelicjańskie, jego zdaniem zbyt surowe i został usunięty z Kościoła, znowu jednak zyskał przebaczenie biskupa, tym razem już Achillasa i został prezbiterem. Doświadczenie uczy, że częste zmiany partii nie przysparzają przyjaciół, może więc i prawdą jest, że to właśnie Melicjusz doniósł Aleksandrowi o nieortodoksyjnych wypowiedziach Ariusza, jak pisze Epifaniusz ${ }^{52}$.

Podsumowując wszystkie te spostrzeżenia możemy hipotetycznie powiedzieć, co następuje. Cesarzowi Konstantynowi zależało na pokoju religijnym w państwie, co w jego pojęciu nie równało się w żaden sposób ujednolicaniu religii. Chrześcijaństwo przyjęte przezeń do grona religii prawnie chronionych znalazło się w ten sposób pod jego kuratelą jako najwyższego pontyfika i uważał się za jego zwierzchnika. Niepokoiła go schizma donacjańska w Afryce, jak i schizma melicjańska w Egipcie i zależało mu na przywróceniu jedności Kościoła. Informacje o sporze Aleksandra z Ariuszem, jakie otrzymał prawdopodobnie dopiero po powrocie z wojny z Licyniuszem, czyli we wrześniu 234 roku, kazały mu myśleć, że oto problemy w Egipcie miast się rozwiązywać, dodatkowo narastają i skłoniło go to do napisania listu stanowiącego przedmiot powyższych analiz. Choć doktrynalny spór traktował jak dyskusje w szkołach filozoficznych, czyli rzecz o małym znaczeniu praktycznym, zdawał sobie sprawę, albo mu to uświadomiono, że jego nałożenie się na problemy związane ze schizmą niweczą jego nadzieje na pokój. Wysłał więc Hozjusza, by spory załagodził i problemy rozwiązał. Trudno sobie wyobrazić, by dopiero po otrzymaniu informacji z Aleksandrii o niepowodzeniu misji Hozjusza, mógł postanowić zwołanie biskupów do Nicei na lato 325 roku, gdyż wydaje się iż materialnie nie byłoby na to czasu. Od 12 listopada nie działała już żegluga na Morzu Śródziemnym, nie miałby więc możliwości wysłania zaproszeń tak, by zainteresowani biskupi mogli je otrzymać w porę, to znaczy przed Wielkanocą, która wypadała w tym roku 18 kwietnia, według wyliczeń aleksandryjskich i by mogli przybyć. Ton listu nawołującego do zgody zdaje się zaś wskazywać na to, że cesarz wierzył w powodzenie misji Hozjusza, czyli w porozumienie między Aleksandrem i Ariuszem. Jeśli by tak było, a zaproszenie na sobór zostałoby

\footnotetext{
${ }^{50}$ Por. SCL $1,82$.

51 Por. Sozomenus, HE I 15.

52 Por. Epiphanius, Panarion 69, 3.
} 
wystosowane już jesienią 324 roku, nie widać, by powodem zwołania soboru miała być kontrowersja ariańska. Powody te jednak były przedmiotem innego mojego studium, do którego pozwalam sobie niniejszym odesłać ${ }^{53}$.

\title{
LETTERA DI COSTANTINO AD ALESSANDRO ED ARIO E LA CONVOCAZIONE DEL CONCILIO NICENO
}

\author{
(Sommario)
}

L'articolo presenta il testo e il commento della lettera dell'Imperatore Costantino, l'unico documento legato alla controversia ariana, per il qual è possibile stabilire la data: fine settembre 324, dopo il ritorno di Costantino dalla guerra con Licinio. L'analisi mette il rilievo l'opinione dell'Imperatore sull'importanza della controversia: che era di poco e che Alessandro e Ario dovrebbero far pace immediatamente. Sembra che questa sia stata opinione non solo di lui, ma anche di chi lo ha informato sull'accaduto, vale a dire - probabilmente - Ossio di Cordoba e forse Eusebio di Nicomedia. Costantino manda la sua lettera sperando che Alessandro e Ario l'avrebbero obbedito, quindi sembra poco probabile che avesse convocato i vescovi a Nicea per risolvere questa controversia.

53 Por. H. Pietras, Le ragioni della convocazione del Concilio Niceno da parte di Costantino il Grande. Un'investigazione storico-teologica, „Gregorianum” 82 (2001) 5-35. 